\title{
HODNOCENÍ INOVAČNÍHO PROSTŘEDÍ POHLEDEM HIGH-TECH FIREM: P̌́ÍPADOVÁ STUDIE JIHOMORAVSKÉHO KRAJE
}

EVALUATION OF INNOVATION ENVIRONMENT BY VIEW OF
HIGH-TECH ENTREPRISES: A CASE STUDY OF SOUTH MORAVIAN
REGION

\section{RNDR. HANA SVOBODOVÁ PH.D.}

\section{DAVID ČOUPEK}

\author{
\begin{tabular}{l|l} 
Katedra geografie & Department of Geography
\end{tabular} \\ Pedagogická fakulta Faculty of Education \\ Masarykova univerzita Masaryk University \\ $\triangle$ Pořiči 7, 60300 Brno, Czech Republic \\ E-mail:hsvobodova@ped.muni.cz,david.coupek@gmail.com
}

\begin{abstract}
Anotace
Jihomoravský kraj je jedním z nejrychleji rostoucich regionu České republiky a střední Evropy v oboru informačnich technologii a vědecko-technických inovací. Tento rüst je však částečně dán podmínkami, které Jihomoravský kraj dlouhodobě vytvárí. Prvním impulzem pro rozvoj bylo zpracováni prvni Regionálni inovačni strategie v rámci České republiky, která napomohla odstartováni dalši podpůrných činností. Jelikož však podniky naráží při své činnosti $i$ na řadu problémů, je cílem př́spěvku analýza vnímani inovačního prostředí v kraji, včetně potenciálu pro rozvoj i bariér, z pohledu high-tech firem, zjištěná pomoci kvalitativniho dotazníkového šetření.
\end{abstract}

\section{Klíčová slova}

high-tech odvětví, inovace, Jihomoravský kraj

\section{Annotation}

South Moravian Region is one of the fastest growing regions in the Czech Republic and also in Central Europe in the field of information technology and scientific and technological innovation. This growth is partly due to the conditions that the South Moravian Region has created. The first impulse for the development was the processing of the first Regional Innovation Strategy of the Czech Republic, which helped to launch other supporting activities. However, as enterprises encounter in their activities to a number of problems, the aim of the paper is analysis of perception of the innovation environment in the region, including the potential for development and barriers in terms of high-tech companies, as determined by the qualitative survey.

Key words

high-tech industry, innovation, South Moravian Region

JEL classification: $L 52,032$

\section{Úvod}

„Z hlediska postavení ekonomiky v globálním produkčním řetězci je důležité, jak významné jsou technologicky náročné aktivity (high-tech odvětví) v dané zemi. Tato odvětví zpravidla přinášejí dané 
ekonomice celou řadu prŕznivých efektů, jako jsou vysoké mzdy a zisky, rychlý růst obchodu a produktivity a vysoká míra inovací, s čímž souvisí i šíření pozitivních externalit“ (Rojíček 2006). $\mathrm{S}$ inovacemi a high-tech odvětvími je nerozdělitelně pojený i pojem klastr (případně další typy sítí), který se $\mathrm{v}$ posledních letech stal v rámci regionálního rozvoje velmi oblíbeným pojmem (Skokan 2002, Ryan, Giblin 2012).

Jihomoravský kraj, zejména díky městu Brnu, patří v rámci České republiky (ČR), ale i Střední Evropy k dynamicky se rozvíjejícím regionům, což dokládá i studie Wokouna et al. (2012), Blažka a Uhlíře (2006) nebo Viturky (2009), kteří hodnotili konkurenceschopnost a inovační potenciálu regionů v ČR.

Kvalitní inovační prostředí v Jihomoravském kraji však nevzniklo samo sebou. Představitelé Jihomoravského kraje si již před vstupem ČR do Evropské unie uvědomovali, že obstát v konkurenci „západních“ regionů bude obtížné a po problémech s poklesem hospodářského růstu a s nezaměstnaností v roce 2002 (v kraji zapř́činěné mimo jiné i vlivem propouštění ve firmě Flextronics a dlouhodobé špatné situaci ve firmě Zetor) začali jednat o strategii, která měla kraj lépe připravit na čerpání dotací z evropských fondů, motivovat investory a směřovat činnost výzkumných a vzdělávacích institucí $\mathrm{k}$ technologicky náročným oborům. Tato strategie byla poměrně velký risk, protože souvisela a stále souvisí s rizikovým kapitálem a nezaručovala, že se vše podaří tak, jak by bylo vhodné. Nicméně od vzniku první Regionální inovační strategie Jihomoravského kraje v roce 2002 a Jihomoravského inovačního centra v roce 2003 se tato činnost jeví jako dobrý a úspěšný krok. V roce 2012 začala př́íprava již čtvrté verze Regionální inovační strategie (on-line), která by měla být originální zapojením i širší laické veřejnosti.

Jelikož však podniky naráží při své činnosti i na řadu problémů, je cílem příspěvku analýza vnímaní inovačního prostředí v kraji, včetně potenciálu pro rozvoj i bariér, z pohledu high-tech firem, zjištěná pomocí kvalitativního dotazníkového šetření.

Metody zpracování

Pro pochopení významu pojmu high-tech odvětví je využita definice Českého statistického úruadu (dále pouze ČSÚ): „High-tech sektor je definován jako soubor ekonomických činností, které ke své produkci ve velké míře používají vyspělé technologie. Zároveň vývoj výstupů z těchto činností doprovází vysoké náklady bud' na inovace a/nebo na výzkum a vývoj. Takovéto ekonomické činnosti zároveň vytvářejí vyšší přidanou hodnotu." (High-tech sektor. ČSÚ, on-line). Do této oblasti patří takové subjekty, jejichž převažující činnost patř́i do následujících skupin a částí CZ-NACE (High-tech sektor: Seznam ekonomických činností High-tech sektoru dle CZ-NACE a OKEČ. ČSÚ, on-line):

- high-tech zpracovatelský průmysl (Výroba farmaceutických výrobků a př́ípravků - oddíl 21, Výroba počítačủ a elektronických součástek - skupiny 26.1, 26.2, Výroba spotřební elektroniky a optických př́strojů - skupiny $26.3,26.4,26.7,26.8$, Výroba měřících, zkušebních, navigačních a léčebných př́strojů - skupiny $26.5,26.6$, Výroba letedel a jejich motorů, kosmických lodí a jejich zařízení - skupina 30.3);

- high-tech služby (Audiovizuální a informační činnosti - oddíly 59, 60, 63, Činnosti v oblasti ICT - oddíly 61, 62, Výzkum a vývoj - oddíl 72).

Pro zjištění současného vztahu firem $\mathrm{k}$ inovačnímu prostředí v Jihomoravském kraji bylo využito online dotazníkového šetření se sadou deseti uzavřených i otevřených otázek. Toto šetření probíhalo od 19. 2. do 8. 3. 2013. Oslovované subjekty byly selektovány $\mathrm{z}$ dat, poskytnutých brněnskou pobočkou Českého statistického úřadu. Z celkového počtu 4349 subjektů ekonomicky činných v high-tech odvětví (3 080 fyzických osob a 1269 osob právnických) byly odstraněny všechny fyzické osoby a subjekty, které neudávaly počet zaměstnanců anebo měly počet zaměstnanců roven nule. Takto bylo získáno celkem 693 ekonomických subjektů z celého Jihomoravského kraje (viz tab. 1), které byly osloveny (z toho 526 (75\%) podniků působí na území okresu Brna-město). Návratnost dotazníku nebyla podle předpokladu př́liš vysoká, nicméně se podařilo získat 110 vyplněných dotazníků, což představuje návratnost 15,8 \% (v okresu Brno-město činila návratnost 14,6 \%). Struktura firem, které 
dotazník vyplnily, odpovídá velikostní i odvětvové struktuře celkového souboru, a proto i tento vzorek lze považovat za reprezentativní.

\section{High-tech odvětví v Jihomoravském kraji}

Poloha Jihomoravského kraje ve střední Evropě při hranici s Rakouskem, Slovenskem a také blízkým Mad'arskem společně s přirozeným centrem - městem Brnem - předurčuje zdejší hospodářské aktivity. Nejen strategická poloha, ale také koncentrace průmyslu, obchodu, vědy a výzkumu, kvalitní pracovní síly (analýzu lidského kapitálu pro potřeby high-tech provedl např. Marvel 2013) a informačních technologií spojených s rozvíjejícím se podnikatelských a inovačním prostředím je hlavním faktorem lákajícím do Jihomoravského kraje nové firmy (tzv. pull faktory; determinanty inovací se zabývala i Knockaert et al. 2013). Mezi další přednosti Jihomoravského kraje lze zařadit i existenci strategických dokumentů, v oblasti inovací a high-tech, zejména již zmiňovanou Regionální inovační strategii.

Koncentrace podniků $\mathrm{v}$ okrese Brno-město podnikajícími v některém $\mathrm{z}$ odvětví high-tech je patrná z tab. 1. Druhé místo zaujímá okres Brno-venkov, jelikož řada podniků je lokalizována v průmyslových/podnikatelských zónách, které jsou těsně za hranicí města Brna (např. průmyslová zóna v Modřicích).

Tab. 1: Velikostní struktura právnických osob podnikajících v high-tech odvětvích vokresech Jihomoravského kraje k 31. 12. 2012

\begin{tabular}{|l|c|c|c|c|c|}
\hline \multicolumn{1}{r|}{ Počet zam. } & $1-49$ & $50-249$ & 250 a více & 0 nebo N/A & Celkem \\
\hline Blansko & 24 & 3 & 0 & 12 & 39 \\
\hline Brno-město & 466 & 50 & 10 & 443 & 969 \\
\hline Brno-venkov & 55 & 1 & 3 & 48 & 107 \\
\hline Břeclav & 26 & 0 & 0 & 17 & 43 \\
\hline Hodonín & 21 & 1 & 1 & 22 & 45 \\
\hline Vyškov & 11 & 0 & 2 & 11 & 24 \\
\hline Znojmo & 19 & 0 & 0 & 23 & 42 \\
\hline Jihomoravský kraj & 622 & 55 & 16 & 576 & 1269 \\
\hline
\end{tabular}

Z hlediska struktury jednotlivých činností dominují firmy zabývající se činnostmi voblasti informačních a komunikačních technologií (ICT). Druhé místo pak zaujímají činnosti audiovizuální a informační, pomyslné třetí místo obsadil výzkum a vývoj. 
Obr. 1: Počet právnických osob podnikajících v high-tech odvětvích dle činností vokresech Jihomoravského kraje k 31. 12. 2012

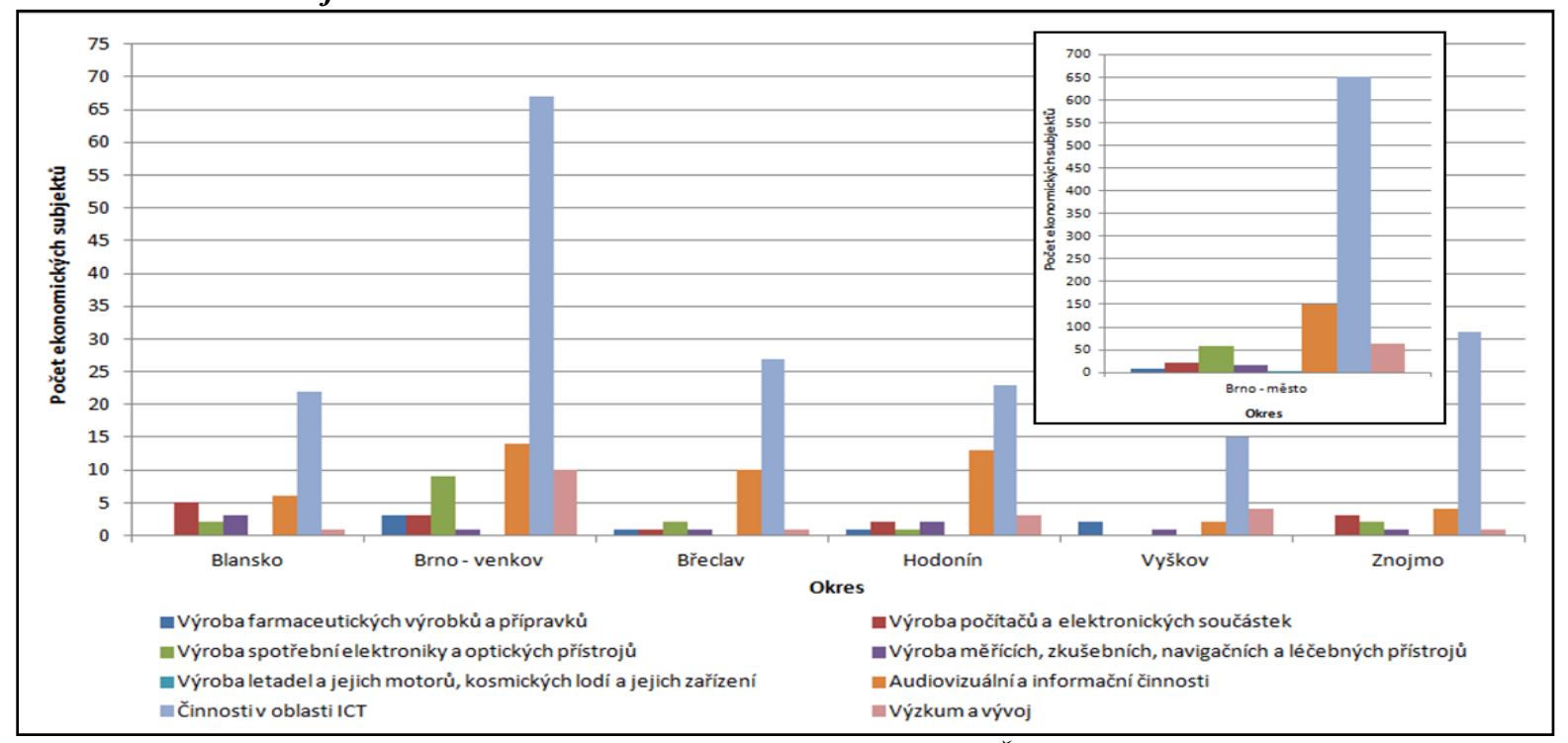

Zdroj: Český statistický úrad, vlastní zpracování

\section{Stav inovačního prostřední z pohledu high-tech podniků}

Z hlediska velikostní struktury se šetření zúčastnila převážná většina - 89,1 \% - malých firem (tzn. do 49 zaměstnanců, z toho převážná většina mikropodniků). Sedm respondenti̊ uvedlo, že jejich podnik náleží mezi středně velké podniky a pět uvedlo, že patři mezi velké podniky. Toto rozdělení zhruba odpovídá velikostní struktuře všech high-tech podniků v kraji, stejně jako odvětvová struktura respondentů.

V otázce, která zjišstovala, zda mají firmy vlastní vývojové centrum, odpovědělo $56,4 \%$ respondentů kladně, 40,0 \% negativně. Pouze čtyři firmy nemají vlastní vývojové centrum, ale mají v plánu ho vybudovat. $Z$ pěti velkých firem všechny odpověděly, že mají své vlastní výzkumné a vývojové centrum. Ze středně velkých firem, trř firmy uvedly, že mají svůj vlastní výzkum a vývoj a čtyři firmy uvedly, že vlastní výzkum a vývoj vůbec nemají a ani s ním nepočítají do budoucna. Z malých firem uvedlo 54 subjektů, že mají vlastní výzkum a vývoj, čtyři firmy uvedly, že nemají, ale plánují ho vytvořit a 40 firem uvedlo, že nemají svoje vlastní výzkumné a vývojové centrum.

Jedním ze základních faktorů rozvoje je spolupráce (Binek, Koráb et al. 2011: 28-40). To platí i v podnicích zabývajících se high-tech aktivitami. Proto další z otázek zjišt'ovala, zda firmy spolupracují nebo využívají služeb výzkumných ústavů či jiných institucí. $65,5 \%$ firem dotazovaných odpovědělo, že s nikým nespolupracuje. 34,5 \% spolupracuje s různými subjekty. Respondenti, kteři odpověděli kladně, následně upřesnili svoji odpověd' v doplňující otázce, z níž vyplývá, že nejčastějš́i spolupráce je mezi firmou a vysokou školou (všechny firmy, které odpověděly kladně), dále jinou soukromou firmou ( 15 z 38 firem), s výzkumným ústavem nebo s institucí veřejné správy (oboje 8 firem z 38).

Jiný typ spolupráce, která firmy mohou využívat je spolupráce či využivání služeb organizací, či zájmových sdružení a jiných subjektů, které podporují inovující firmy (např. JIC). Ze 110 firem odpovědělo $94(85,5 \%)$, že nevyužívají žádných služeb a pouze $15(13,6 \%)$ uvedlo, že využivají těchto služeb pro podporu inovujících firem. $Z$ těchto 15 firem, které nějakým způsobem spolupracují, uvedlo pět subjektů spolupráci př́mo s Jihomoravským inovačním centrem. Dvě firmy uvedly spolupráci s Vysokým učením technickým v Brně a Masarykovou univerzitou, jedna firma spolupracuje s Vojenským výzkumným ústavem. Zajímavé jsou odpovědi, kdy firmy uvedly spolupráci se subjekty a institucemi, jako je AISEC (Studentská organizace, která sdružuje studenty z více než 110 zemí celého světa a umožňuje jim různé stáže. Spolupracujícím firmám umožňuje 
vyhledat a zaměstnat studenta s takovou oborovou profilací, která zajistí jeho přínos pro firmu. /Podle: AIESEC, on-line/. Tato spolupráce se jeví jako výhodná, zejména protože v současné době se firmy potýkají s nízkými praktickými zkušenostmi absolventů, kteří nejsou schopni se ihned začlenit do struktury firmy bez dalších doškolování.), Regionální hospodářská komora Brno (zajišt’uje podporu podnikatelských aktivit a prosazování a ochranu zájmů členských firem, poskytuje služby v oblasti vzdělávání, finančního poradenství atd. /podle: Regionální hospodářská komora Brno, on-line/) a Czech Invest.

Také spolupráce $\mathrm{v}$ rámci klastru nebo podnikatelských inkubátorů není zatím $\mathrm{v}$ Jihomoravském kraji př́lišs rozvinutá. Pouze devět firem uvedlo, že jsou součástí takovéhoto typu spolupráce, ostatní firmy nejsou inkubovány ani nejsou členy některého klastru. $Z$ devíti firem, které odpověděly kladně, jsou tři, které uvedly, že spolupracují s Jihomoravským inovačním centrem, jedna firma je začleněna do Biotechnologického inkubátoru a dvě firmy uvedly, že nejsou inkubovány, ale fungují jako spolupracující subjekt. Jedna firma náleží do Podnikatelského inkubátoru Brno - Jih. Dvě firmy uvedly, že jsou členy Network Security Monitoring Clusteru (kooperační odvětvové uskupení zaměřené na oblast bezpečnosti počítačových sítí a bezpečnosti v ICT; podle: http://www.nsmcluster.com/). Ostatní respondenti neuvedli v druhé části dotazníku, jakého sdružení jsou členem.

Výhody členství v různých sítích jsou mnohé. Z pěti respondenti̊, kteří přínosy vyjmenovali je patrné, že mezi hlavní výhody patř́: , Spolupráce s firmami podobného zaměření. Př́spěvky na prezentace firem na veletrzích, pořádáni rüzných akcí a setkání pro podnikatele. " Dále také firmy uváděly jako výhodu: ,,levnějš́ nájem a některé služby a vzájemnou pomoc v oblastech, které některé firmy nepokrývaji. “V odpovědích se však objevily i nevýhody jako: „Umi pomoci jen velmi malým firmám, nezaměřují se na podstatné věci. " Jeden z respondentů měl poměrně negativní zkušenost: ,, Inkubátor žije na vašem výzkumu, alespoň ten co jsme s ním kdysi jednali. Dnes nemá ani cenu sdělovat nejnovějši věci z dưvodů konkurence a jeho kopírování bez souhlasu ... Technologie typu vzorců, postupu a podobné nelze chránit... Operační program nemá smysl - stejně jej je nutné úvěrovat a potom teprve dostaneme penize (na rozdíl od Němců apod.). ... Čerpání nestojí za nic, protože nápady nelze synchronizovat s nějakými pochybnými programy!!! (upraveno do publikovatelné verze).

Z odpovědí je jasné, že členství v těchto subjektech má své výhody i nevýhody a určitě je ještě stále na čem pracovat $\mathrm{k}$ jeho zdokonalení. Bohužel nízký počet odpovědí znemožňuje vytvoření objektivnějšího názoru.

Další téma, které bylo v dotazníku řešeno, bylo využívání financí z operačních programů a náročnost administrativy při podávání žádosti. Ze 110 respondentů využilo financí z některého operačního programu pouze 29 firem (26,4 \%), a to i přesto, že Jihomoravský kraj je regionem, ve kterém je v rámci ČR realizováno nejvíce projektů z Operačního programu (dále pouze OP) Podnikání a inovace (viz obr. 2; hl. město Praha nemůže z OP čerpat), což dokazuje silnou pozici a snahu o rozvoj u podniků v kraji. Právě OP Podnikání a Inovace byl respondenty uveden v pěti př́padech, dále byl uveden OP Výzkum a vývoj pro inovace, OP Lidské zdroje a zaměstnanost a OP Vzdělávání pro konkurenceschopnost. Program Czech Investu - ICT a strategické služby byl uveden v odpovědích dvakrát. Také dvě firmy uvedly, že se zúčastnily programů Technologické agentury České republiky - Centra kompetence a programu Alfa. Jedna firma využila program TANDEM a čtyři firmy využily program TIP od Ministerstva průmyslu a obchodu. Jeden respondent uvedl zapojení do programu Ministerstva práce a sociálních věcí - Školení je šance. Dva respondenti uvedli opakované zapojení do rámcových programů Evropské unie FP5, FP6 a FP7. 
Obr. 2: Počet úspěšných projektů ze strukturálních fondi̊ OPPI v krajích ČR (k 15. 4. 2013)

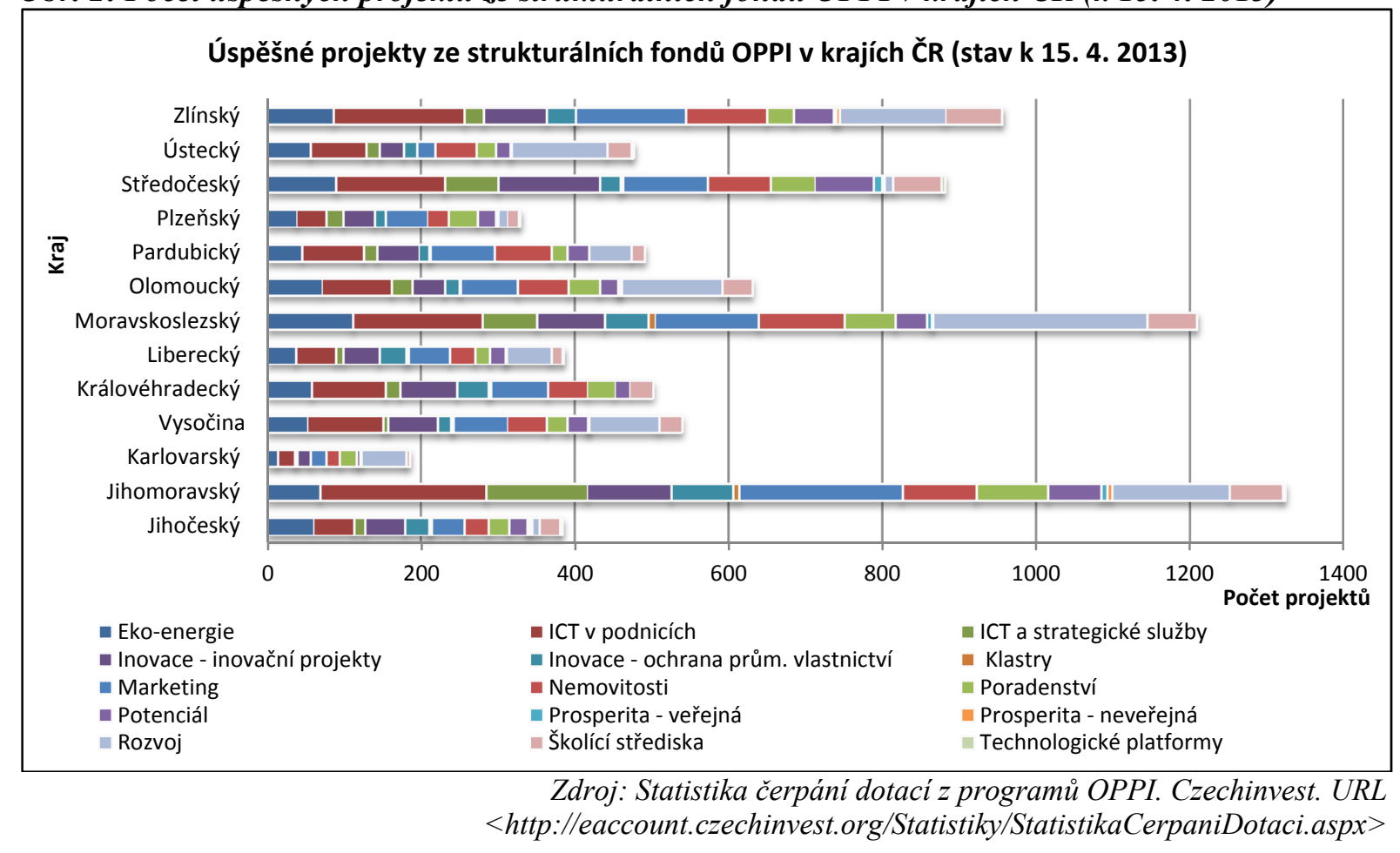

Administrativa procesu podávání žádosti a čerpání zdrojů z operačních programů se jeví 71 firmám $(64,5 \%)$ jako složitá. Odpověd” „nevím“ zvolilo celkem 31 respondentů (logicky těch, kteří o dotace zatím nežádali) a odpověd' ne zvolilo osm firem. Odpovědi tedy jasně ukazují, že většina firem je toho názoru, že administrativa spojená se získáváním dotací, je skutečně složitá. Je dokonce velmi pravděpodobné, že náročná administrativa stojí za odrazením některých firem od čerpání těchto zdrojů.

Problémy s dotačními zdroji se objevovaly i u předposlední otázky: „Narazila vaše firma při svém podnikání na nějaké překážky?“. Na tuto otázku odpovědělo kladně 75 respondentů $(68,2 \%)$ a záporně 35 . Nejčastěji firmy uváděly jako překážku nedostatek kvalifikované pracovní síly, a to v 59 př́padech. Ve 26 prrípadech uvedly problémy se získáváním financí pro svoji činnost a 16 respondentů odpovědělo, že jejich firma trpí nedostatkem subjektů pro spolupráci. Ve 26 př́padech uvedly jiné překážky, jako státní byrokracii, legislativu a s ní spojené neustálé změny zákonů a předpisů Evropské unie a dále také nejasná výběrová ř́zení. Jeden respondent dokonce uvedl, že po něm byl požadován úplatek při žádosti o čerpání dotací z fondů. Další uváděl současnou neochotu zákazníků investovat, vlivem probíhající ekonomické krize. Z odpovědí na tuto otázku vyplývá, že i když Jihomoravský kraj, a zejména město Brno, je městem s koncentrací vysokých škol, přesto firmy trpí nedostatkem kvalifikované pracovní síly.

\section{Obr. 2: Překážky podnikání high-tech firem}

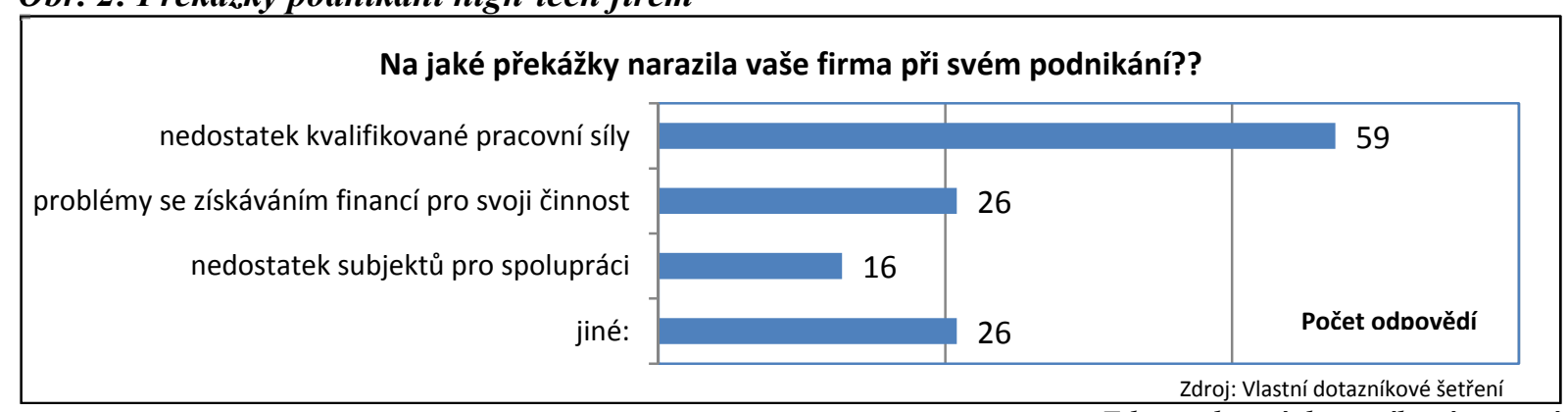

Zdroj: vlastní dotaznikové šetření 
Poslední otázka hodnotila inovační prostředí $\mathrm{v}$ Jihomoravském kraji. V této otázce nejvíce respondentů uvedlo, že shledávají podmínky pro inovace v Jihomoravském kraji za průměrné (86 subjektů, tj. 78,2 \%). Podle 15 firem jsou v Jihomoravském kraji nepř́íznivé podmínky pro inovace a devět firem označilo podmínky pro inovace za výborné.

\section{Závěr}

Odpovědi high-tech firem z Jihomoravského kraje ukázaly, že inovační prostředí kraje není optimální. Kromě vnějších nedostatků, mezi něž lze zařadit zejména byrokracii a náročnou administrativu při čerpání podpůrných zdrojů, však existují bariéry i uvnitř firem, co je patrné zejména z nízké intenzity spolupráce (at' už $\mathrm{v}$ rámci klastrů, spolupráce $\mathrm{s}$ výzkumnými ústavy nebo členství v profesních organizacích). Toto může být výraznou bariérou při difúzi inovací (blíže Blažek, Uhliř 2011). Poněkud překvapivé je, že řada firem postrádá kvalifikovanou pracovní sílu.

Pozitivní je, že více než polovina dotazovaných firem má vlastní výzkumné a vývojové centrum, což částečně vyvrací to, že Česká republiky je pouze „montovna“ bez tvorby př̌idané hodnoty. Vlastnictví vlastního výzkumného nebo vývojového centra umožňuje vyvíjet nové procesy a postupy, které zvyšují přidanou hodnotu finálních výrobků a které se stávají zajímavé nejen pro náš, ale i pro zahraniční trh, a tím pádem se zviditelňuje i Jihomoravský kraj jako inovativní region.

Jihomoravský kraj tak má podle výsledků šetření stále co zlepšovat. Na druhou stranu je v rámci krajů České republiky v oblasti high-tech a inovací na špici, což je podpořeno kvalitní činností JIC a ale samozřejmě i samotných firem.

\section{Literatura}

[1] BLAŽEK, J., UHLÍŘ, D. Teorie regionálního rozvoje. Praha: Karolinum, 2011. 344 s. ISBN 9788024619743.

[2] BLAŽEK, J., UHLÍř, D. Regional Innovation Policies in the Czech Republic and the Case of Prague: An Emerging Role of a Regional Level? European Planning Studies. Vol. 15, Issue 7, 2007. pp. 871-888. DOI: 10.1080/09654310701356175.

[3] BINEK, J., KORÁB, V. et al. Obce a regiony pro podnikatele \& Podnikatelé pro obce a regiony. 1. vyd. Brno: GaREP, spol. s r.o., 2011. 120 s. ISBN 978-80-905139-0-7.

[4] HIGH-tech sektor. Praha: Český statistický úřad. Dostupné z: $<\mathrm{http}: / /$ www.czso.cz/csu/redakce.nsf/i/high_tech_sektor> [cit. 24. 1. 2013].

[5] HIGH-tech sektor: Seznam ekonomických činnosti High-tech sektoru dle CZ-NACE a OKEČ. Praha: Český statistický úr̆ad. Dostupné z: $<$ http://www.czso.cz/csu/redakce.nsf/i/seznam_ekonomickych_cinnosti_high_tech_sektoru_dle_c z_nace_a_okec/\$File/01_seznam_ekonomickych_cinnosti_ht_sektoru.pdf $>$ [cit. 24. 1. 2013].

[6] KNOCKĀERT, M., VANDENBROUCKE, E., HUYGHE, A. Unraveling the need for innovation support services in new technology-based firms: The impact of commercialization strategy. Science and public policy, Vol. 40, Issue 1. 2013. pp. 85-96. DOI: 10.1093/scipol/scs060.

[7] MARVEL, M. R. Human Capital and Search-Based Discovery: A Study of High-Tech Entrepreneurship. Entrepreneurship theory and practice. Vol. 37, Issue 2. 2013. pp. 403-419. DOI: $10.1111 / \mathrm{j} .1540-6520.2011 .00465 . \mathrm{x}$.

[8] Network Security Monitoring Cluster. URL <http://www.nsmcluster.com/> [cit. 10. 4. 2013]

[9] Regionální hospodářská komora Brno. O nás. Dostupné z: <http://www.rhkbrno.cz/o-nas/okomore> [cit. 25. 3. 2013].

[10] Regionálni inovačni strategie Jihomoravského kraje. Co je to RIS? Dostupné z: $<$ http://www.risjmk.cz/cz/co-je-to-ris/> [cit. 16. 4. 2013].

[11] ROJÍČEK, M. Strukturální analýza české ekonomiky. Working Paper CES VŠEM No. 3/2007. Praha: VŠE, 2007. Dostupné z: <http://sis.vsem.cz/data/data/ces-soubory/konferenceseminare/gf_RojicekHK.pdf> [cit. 7. 4. 2013] 
[12] RYAN, P., GIBLIN, M. High-tech Clusters, Innovation Capabilities and Technological Entrepreneurship: Evidence from Ireland. World Economy, Vol. 35, Issue 10. pp. 1322-1339, 2013. DOI: 10.1111/j.1467-9701.2012.01486.x.

[13] SKOKAN, K. Industry Clusters in Regional Development. Ostrava: VSB-Technical University of Ostrava, The Faculty of Economics, 2002. Dostupné z: <http://mpra.ub.unimuenchen.de/12372/1/MPRA_paper_12372.pdf $>$ [cit. 14. 4. 2013]

[14] Statistika čerpání dotací $z$ programů OPPI. Praha: CzechInvest. Dostupné z: $<$ http://eaccount.czechinvest.org/Statistiky/StatistikaCerpaniDotaci.aspx $>$

[15] VITURKA, M. Competitiveness of regions in the light of global economy. Case study of the Czech regions. In Wilk, W. (ed.) Global Changes: Their Regional and Local Aspects. Warsaw: University of Warsaw, 2009. s. 301-312, 12 s. ISBN 978-83-89502-73-5.

[16] WOKOUN, R., DAMBORSKÝ, M., KOUŘILOVÁ, J., KREJČOVÁ, N. The Competitiveness of Regions in the EU. The Competitiveness of Regions in the EU. In ERSA - Regions in Motion: Breaking the Path. Bratislava: European Regional Science Association, 2012. Dostupné z: $<$ http://www-sre.wu.ac.at/ersa/ersaconfs/ersa12/e120821aFinal00790.pdf $>$ [cit. 21. 4. 2013] 